\title{
Re-envisioning local government studies, research and practice for the future
}

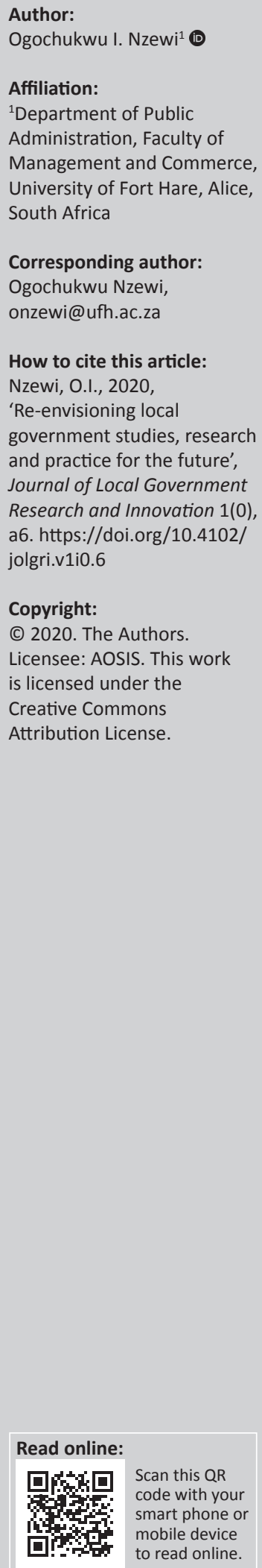

In 2015, at the height of the migrant crisis, about 150000 refugees landed in Italy and 800000 in Greece (Clayton \& Holland 2015). While the spectacle of arriving rescue boats teeming with refugees captivated the world, receiving less attention, pivotal to the crisis were local officials of municipalities across Italy and Greece, who had to manage and prepare their municipalities for the potential absorption and impact of the refugee crises. In 2019, just like many years before, South African municipalities witnessed countless service delivery protests by citizens disgruntled with the poor pace and lack of service delivery in their communities. In some cases (as was the case in the North West province, where community members burnt down the houses of six local councillors), officials and existing municipal infrastructure suffer the brunt of the anger of citizens (Tau 2019). Crises ranging from emergency housing to healthcare highlight the role of the local government as the coalface of policy delivery and impact.

Local basic services are identified as a basic human right. These services include basic services like waste collection, transport, water and sanitation; quality of life services such as public safety and public spaces; and social services, such as housing, health, education and care for the elderly and children. The implication is that real change and policy effectiveness are locally contextualised and as such highlight the unique position of the local government as the epicentre of service delivery. Because real change is locally contextualised, local governments are also the ground zero for social, political and economic action or change. In this sense, the repercussions of policy failure, such as the migrant crisis, housing crisis, environmental hazards, gender inequality and disruptions in social cohesion and inclusion, become the burden of local governments.

From urban municipalities or cities to rural and traditional communities, local governments operate in a very complex space because of the diversity in citizen representations, needs, and political and social orientation, to mention but a few. Thus, flexibility in local government is critical and is globally viewed as an accepted practice. Indeed, cities and municipalities across the globe have become centres for innovation and research through focus on alternative service delivery models best suited to their unique needs. From slum upgrading to the development of smart cities, innovation in local government has the potential to become a global source of knowledge creation and sharing towards practice learning and adoption. Notwithstanding these possibilities, local governments especially in developing regions like Africa still grapple with basic challenges, such as affordability, shortages in funding, limited capacity, building momentum for alternative services and innovation, historical spatial development legacies and climate change adaptation (United Cities and Local Governments 2013:29-30). These challenges present opportunities for learning. Therefore, from a practice perspective, there is a need for broader knowledge sharing and collaboration on local governance initiatives and alternative service delivery models globally.

From a disciplinary viewpoint, local government studies, and public administration in general, embrace multiple disciplinary (inter-, trans- and multidisciplinary) approaches. Although the history of the discipline demonstrates a lingering struggle for an exclusive disciplinary space, its political science and law roots, and embrace of modern management techniques as well as advances in technology, indicate a public administration that cannot disaffirm this inter-, trans- and multidisciplinary approach. Moreover, government administration necessitates that research and innovation consider developments in the functional departments of government, such as engineering, environmental management and infrastructure. Nevertheless, public administration rather tends to view innovation (e.g. technology) as ex post facto research areas where what exists is studied, as opposed to where the creation and promotion of pioneering research from study to the practice space is pursued.

There is a growing urgency for effective service delivery in the local government. The capable state's role is therefore to uncover and utilise within constitutional and regulatory parameters, 
creative and unique approaches to effective service delivery through the embrace of alternative service delivery models. Furthermore, avenues and platforms to apply much of the innovative and creative local government-focused research findings coming from public administration departments across the globe, are limited. This is despite indications that a considerable number of research and publications in public administration are centred on local government issues. This journal seeks to provide a unique space for knowledge sharing and utilisation on alternative service delivery models from research to practice and vice versa.

\section{Aim and scope of the journal}

The Journal of Local Government Research and Innovation (JOLGRI) is an international and multiple disciplinary journal, which provides a platform for scholars, practitioners and opinion leaders to publish quality research focused on innovative and alternative approaches and models in service delivery and governance in local government. Thus, the point of departure of this journal from other local government-focused journals lies in the positioning of innovation and research as a sine qua non for the development of local government. This entails putting multiple disciplinary approaches at the front and centre as a knowledge development priority towards educational, epistemological and practice advancements in local government. Thus, the journal welcomes articles written for a broad audience of academics, students and practitioners from multiple discipline and practice areas that have significant relevance to local government.

The journal adopts a rigorous blind peer-review process and a rolling publication system, which encourages prompt publication of accepted papers. It includes research articles, notes, conceptual reviews and essays as well as practitioner-focused papers, which promote multidisciplinary and original research on local government innovation and practice. Manuscripts are welcome from South Africa, Africa and across the globe.

\section{Podcasts}

The journal also develops podcasts on important areas of local government practice and research (e.g. local government budgeting, service delivery challenges and responses, managing local government human resources and so on). The podcast will feature authors of high impact and interesting articles published in the journals, as well as important actors in local government research and practice in South Africa, Africa and across the globe. We are optimistic that the podcasts can be used to advance teaching and practice where possible.

\section{Emerging researchers' mentorship programme}

The journal will offer avenues for young research academics and graduate students to grow their academic research publication agenda through publications. The programme will offer editorial advice and consultation prior to the submission of a manuscript for publication.

\section{References}

Clayton, J. \& Holland, H., 2015, 'Over one million sea arrivals reach Europe in 2015', in T. Gaynor (ed.), UN Refugee Agency, viewed 12 September 2019, from https:// www.unhcr.org/news/latest/2015/12/5683d0b56/million-sea-arrivals-reacheurope-2015.html.

Tau, P. 2019, 6 ANC councillors' houses among 8 torched in violent North West protest City Press, viewed 19 September 2019, from https://city-press.news24.com/ News/7-anc-councillors-houses-torched-in-violent-north-west-protest-20190917.

United Cities and Local Governments, 2013, Basic services for all in an urbanising world: Third global report of united cities and local governments on local democracy and decentralization (GOLD III), United Cities and Local Governments, democracy
Barcelona. 